\title{
Distribution and impact of the alien anemone Sagartia ornata in the West Coast National Park
}

\begin{tabular}{|c|}
\hline $\begin{array}{l}\text { Authors: } \\
\text { Tamara B. Robinson }{ }^{1} \\
\text { Cheruscha Swart }^{1}\end{array}$ \\
\hline $\begin{array}{l}\text { Affiliations: } \\
{ }^{1} \text { Department of Botany and } \\
\text { Zoology, Centre for Invasion } \\
\text { Biology, Stellenbosch } \\
\text { University, South Africa }\end{array}$ \\
\hline $\begin{array}{l}\text { Correspondence to: } \\
\text { Tamara Robinson }\end{array}$ \\
\hline $\begin{array}{l}\text { Email: } \\
\text { trobins@sun.ac.za }\end{array}$ \\
\hline $\begin{array}{l}\text { Postal address: } \\
\text { Private Bag X1, Matieland } \\
7602 \text {, South Africa }\end{array}$ \\
\hline $\begin{array}{l}\text { Dates: } \\
\text { Received: } 05 \text { Aug. } 2014 \\
\text { Accepted: } 23 \text { Sept. } 2014 \\
\text { Published: } 25 \text { Mar. } 2015\end{array}$ \\
\hline $\begin{array}{l}\text { How to cite this article: } \\
\text { Robinson, T.B. \& Swart, } \\
\text { C., 2015, 'Distribution and } \\
\text { impact of the alien anemon } \\
\text { Sagartia ornata in the West } \\
\text { Coast National Park', Koedoe } \\
57(1) \text {, Art. \#1246, } 8 \text { pages. } \\
\text { http://dx.doi.org/10.4102/ } \\
\text { koedoe.v57i1.1246 }\end{array}$ \\
\hline $\begin{array}{l}\text { Copyright: } \\
\text { (C) 2015. The Authors. } \\
\text { Licensee: AOSIS } \\
\text { OpenJournals. This work is } \\
\text { licensed under the Creative } \\
\text { Commons Attribution } \\
\text { License. }\end{array}$ \\
\hline
\end{tabular}

Read online:

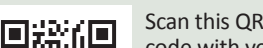

code with your

smart phone or

mobile device

to read online.
Sagartia ornata is an alien anemone that occurs intertidally within the West Coast National Park (WCNP). Whilst baseline distributional data was gathered in 2001, the range and abundance of this alien has not been reassessed. The present study aimed to determine the current status and distribution of this anemone, to assess its diet so as to establish the role it may play as predator and to investigate its impact on sandy-shore communities. Sagartia ornata was found to be restricted to the WCNP, where it occurred in densities of up to $508 \pm 218$ individuals per $\mathrm{m}^{2}$. Within the park the distribution of this anemone had changed. Populations were recorded in Nanozostera capensis seagrass beds for the first time and this alien was absent from two areas in which it had previously occurred. Diet analysis revealed indigenous polychaetes and amphipods as the dominant prey items consumed by S. ornata. This alien was found to significantly alter sandy-shore community structure, with differences caused primarily by increases in the abundance and biomass of the tanaid Anatanais gracilis and the polychaete Orbinia angrapequensis. Additionally, invaded areas supported significantly greater invertebrate diversity, density and biomass. It is concluded that whilst this anemone negatively affects native biota, its current dependence on restricted habitats precludes widespread impacts with the park.

Conservation implications: With regard to conservation implications, this invasion should be routinely monitored outside the WCNP as in its native range $S$. ornata occurs on rocky shores and kelp holdfasts, suggesting a potential for spread along the west coast of South Africa.

\section{Introduction}

The human-mediated spread of marine species from their natural ranges to new habitats is occurring with increasing frequency (Seebens, Gastner \& Blasius 2013) and resulting invasions have been reported from most regions (Molnar et al. 2008). These invasions result primarily from shipping, the main vector being ship hull fouling (Hewitt, Gollasch \& Minchin 2009; Mead et al. 2011a). Other shipping-related vectors include ballast water (Klein et al. 2010) and sediment retained in ballast tanks (Briski, Bailey \& MacIsaac 2011). The increase in the number of ships and ballast tank size (Carlton 1996), accompanied by an increase in transoceanic travel (Ruiz et al. 1997) over the last century, has led to an increase in the introduction and rate of establishment of invasive marine species around the world (Wonham et al. 2000). This is cause for concern as these alien species can pose a threat to indigenous biota (Gurevitch \& Padilla 2004; Molnar et al. 2008; Strain \& Johnson 2013) and can have negative economic impacts (Cinar 2013; Pimentel, Zuniga \& Morrison 2005).

In South Africa, 90 introduced and 39 cryptogenic species have been recognised to date (Bolton, Andreakis \& Anderson 2011; Clark \& Griffiths 2012; Mead et al. 2011b; Peters et al. 2014), although this is likely to be an underestimation as alien species are continuously being introduced into the country. Most introductions are recorded along the cool-temperate west coast (Mead et al. 2011a); most occurring within harbours, a moderate number on rocky shores and in estuaries and very few offshore (Mead et al. 2011a). Following global trends, most species alien to South African waters have been introduced via hull fouling and ballast water (Mead et al. 2013).

The West Coast National Park (WCNP) is situated in the Saldanha Bay system on the cold west coast of South Africa and includes Langebaan Lagoon (Robinson, Griffiths \& Kruger 2004). It was established in 1985 and is the only national park for the protection and conservation of marine species north of the Cape Peninsula (Robinson et al. 2004). The WCNP faces numerous threats, including increased pollution within the bay owing to industrial development and urbanisation (Kruger et al. 2005), expanding mariculture (Olivier, Heinecken \& Jackson 2013) and the introduction of marine alien species associated with the port (Robinson et al. 2004). Presently 
more alien marine species occur within the Saldanha BayLangebaan Lagoon system than in any other location along the South African coast (Mead et al. 2011a).

The alien anemone Sagartia ornata was first recorded along Langebaan Lagoon's western shoreline in 2001 in the upper intertidal zone (Acuña, Excoffon \& Griffiths 2004). Here, S. ornata was found intertidally on sandy shores partially covering the underlying rocks and in Spartina maritima beds (Robinson et al. 2004), where its densities reached up to $426 \pm 81$ (s.d.) individuals per $\mathrm{m}^{2}$ (Robinson et al. 2005). Sagartia ornata's introduction to the lagoon is thought to have occurred unintentionally through shipping via the harbour of Saldanha Bay (Robinson et al. 2004). It is most likely that the introduction is recent, as extensive annual sampling of the lagoon failed to detect this anemone until 2001 (Acuña et al. 2004). This species originates from Western Europe, the Mediterranean and Britain (Robinson et al. 2004). There it is found widely occurring on kelp holdfasts and in crevices on rocky shores (Gibson, Hextall \& Rogers 2001). Thus, the South African west coast, known for its cold water, rocky shores and extensive kelp beds, is very similar to S. ornata's native home range (Acuña et al. 2004) and much potential exists for this species to spread along this coast. Despite this, S. ornata's distribution and abundance was last assessed more than 10 years ago (Robinson et al. 2004) and its impact on indigenous sandy-shore communities has not been considered. This is a notable gap in current knowledge as sea anemones can play an important role in marine communities through their role as predators (Kruger \& Griffiths 1998).

Against this background, this study aimed firstly to determine the current status and distribution of $S$. ornata, secondly to assess the diet of this anemone so as to establish its role as an alien predator and thirdly to investigate its impact on the structure of the sandy-shore communities of invaded areas in Langebaan Lagoon.

\section{Research method and design \\ Setting}

This study was conducted within Langebaan Lagoon in the WCNP (Figure 1). The lagoon forms a wetland of international importance and is registered under the Ramsar and Bonn conventions. The lagoon opens into the southern end of Saldanha Bay (Pitcher \& Calder 1998) and consists of sandflats with clean, fine sand as well as salt marshes. The lagoon supports a great diversity of marine taxa, many of which are not found elsewhere along the west coast or are restricted to estuarine environments (Robinson \& Griffiths 2002).

\section{Distribution and abundance of Sagartia ornata}

Sampling was undertaken in April and May 2013. The lagoon was divided into areas of $3 \mathrm{~km}$, following Robinson et al. (2004) (Figure 1). Boundaries of areas used remain the same although the areas have been renumbered 1-15 for

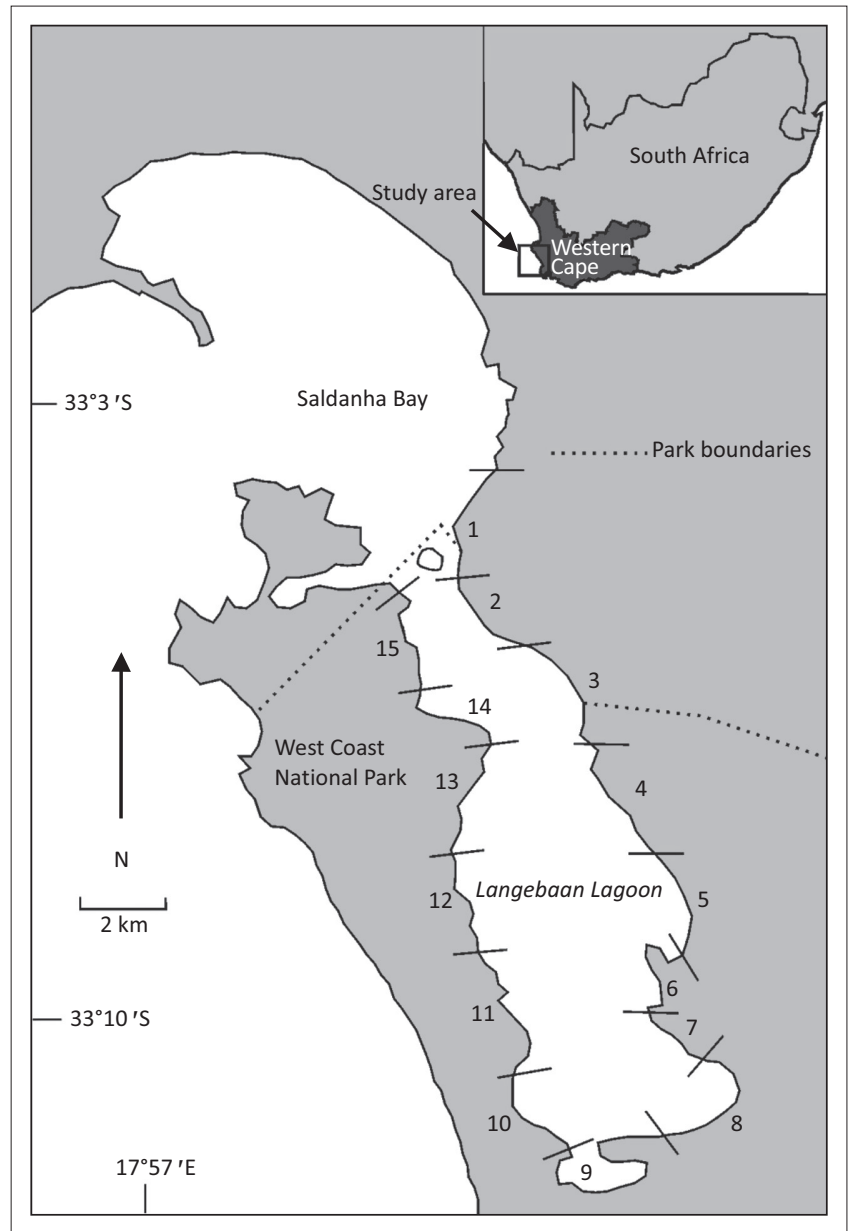

Source: Authors' own creation

FIGURE 1: Map of Saldanha Bay and Langebaan Lagoon, showing the 15 study areas which were sampled as well as the West Coast National Park boundaries.

convenience. Areas supporting suitable habitat (containing S. maritima beds or sand-covered rocks) were visited. In areas where the anemone was detected 10 quadrates of $0.25 \mathrm{~m}^{2}$ were randomly placed in each shore zone (high-, mid- and low-shore zones) and the number of anemones recorded. In addition, areas outside of the WCNP but within Saldanha Bay (i.e. Marcus Island, Small Bay and Lynch Point), as well as rocky shores $10 \mathrm{~km}$ north (i.e. Jacobs Bay) and south (i.e. Tsaarsbank) of the mouth of the bay were searched to determine if this species had spread outside the park.

\section{Coelenteron contents analysis}

To assess S. ornata's role as a predator, the coelenteron contents of 50 individuals that were collected randomly in various habitats around the lagoon were analysed. Anemones were collected during low spring tide and each was placed into a separate jar. To each jar a mixture of one part sea water and one part $10 \%$ magnesium chloride $\left(\mathrm{MgCl}_{2}\right)$ solution was added to relax and narcotise the anemones. These were then frozen at $-4{ }^{\circ} \mathrm{C}$. To collect any organisms egested during the period of transportation and preservation, the liquid from each jar was poured through a $15 \mu \mathrm{m}$ mesh prior to processing. A dissecting microscope was used to examine the retrieved organisms and the anemones. 
The anemones were cut longitudinally to open their coelenterons and prey items were removed. Prey items were identified to the lowest taxonomic group possible, counted and their wet-mass recorded. The shells of hard-shelled animals were also included in the weighing process. Inedible items such as exoskeletons, empty shells and debris, as well as unidentifiable detritus were excluded from analysis, as it was unclear whether these items were ingested as debris or are parts of digested prey. The number of prey and the total mass of prey consumed by each anemone was expressed as a percentage. The percentage frequency of occurrence of each of the different types of prey organisms was determined. An index of relative importance (IRI) was calculated for each prey species as an indication of the importance of each food item in the diet of $S$. ornata. These calculations were made using the following equation (Berg 1979):

$I R I=(\% \mathrm{~N}+\% \mathrm{M}) \times \% \mathrm{~F}$

[Eqn 1]

where: $\% \mathrm{~N}=$ average numerical percentage occurrence of each item in the diet; $\% \mathrm{M}=$ average percentage by mass of food item in all the guts examined; $\% \mathrm{~F}=$ frequency of occurrence of the food item.

Sample sizes were represented by the number of coelenterons examined that contained food items. Occurrence is thus expressed as the percentage of coelenterons containing food in which each particular food category was found.

\section{Community structure}

To determine the impact of $S$. ornata on community structure, community composition was compared between an invaded and uninvaded area. The areas were located in the mid-shore zone, as this was the zone where $S$. ornata was found. In each area, 10 randomly placed quadrats of $0.25 \mathrm{~m}^{2}$ were used to quantify community composition. All sediment within each quadrat was removed until the underlying rock to which the anemones were attached was reached (a depth of not more than $10 \mathrm{~cm}$ ). This sediment was sieved through a $1 \mathrm{~mm}$ sieve to retain organisms occurring within the sediment. All biota recovered from above and below ground were identified to species level, counted and wet-weighed.

\section{Statistical analyses}

Prior to all univariate analysis, data were tested for homoscedasity and homogeneity of variances using STATISTICA for Windows (Version 11). The abundance of the anemones recorded in each area was compared to that recorded in 2001 (Robinson et al. 2004). A generalised least square (GLS) model was used to determine the effect of area and year on the abundance of anemones. The dredge function in R Studio (Version 5.1) was used to select the model that best explained anemone abundance. The best model was selected based on the lowest Akaike information criterion. Invertebrate abundance (individuals per $\mathrm{m}^{2}$ ) and biomass ( $\mathrm{g}$ per $\mathrm{m}^{2}$ ) were compared between invaded and uninvaded sites using a Mann-Whitney $U$ test.
The PRIMER software package (Plymouth Marine Laboratory, Plymouth, UK) was used to consider community composition (based on numerical abundance and biomass) in invaded and uninvaded areas. To detect significant differences between the communities of the two sites, ANOSIM (based on BrayCurtis similarities) was used. A SIMPER analysis identified the species which contributed most to any differences detected. Non-metric multidimensional scaling (MDS) plots and hierarchical cluster analysis was used to create a visual representation of any differences between communities. All multivariate analyses were carried out on fourth-root transformed non-standardised data. To complement the analysis of community composition, the Shannon-Wiener diversity index $\left(H^{\prime}\right)$ was used to assess the species diversity of each site (Clarke \& Warwick 2001):

$H^{\prime}=-\sum i \mathrm{p}_{i}\left(\log \mathrm{p}_{i}\right)$

[Eqn 2]

where $\mathrm{p}_{i}$ is the proportion of the total number of individuals arising from the $i$ th species. This index was compared between invaded and uninvaded sites using a Mann-Whitney $U$ test.

\section{Results}

\section{Distribution and abundance of Sagartia ornata}

Sagartia ornata occurred in the mid-shore zone. The abundance of $S$. ornata individuals differed significantly between areas (GLS, $F_{(7)}=13.67, p<0.01$ ) and years (GLS, $F_{(1)}=12.25$, $p<0.01)$, with more anemones being recorded in areas 2,10 and 14 in $2013(t=3.6, p<0.01)(2)$. The presence of S. ornata was recorded in areas $3\left(6.0+2.4[\mathrm{SE}]\right.$ individuals per $\left.\mathrm{m}^{2}\right)$ and $5\left(3.6+2.2[\mathrm{SE}]\right.$ individuals per $\left.\mathrm{m}^{2}\right)$ for the first time in 2013 whilst it no longer occurred in areas 9 and 13. High densities of the alien anemone were maintained through time in area $14(372.6+24.7[\mathrm{SE}]$ and $508.4+69.1[\mathrm{SE}]$ in 2001 and

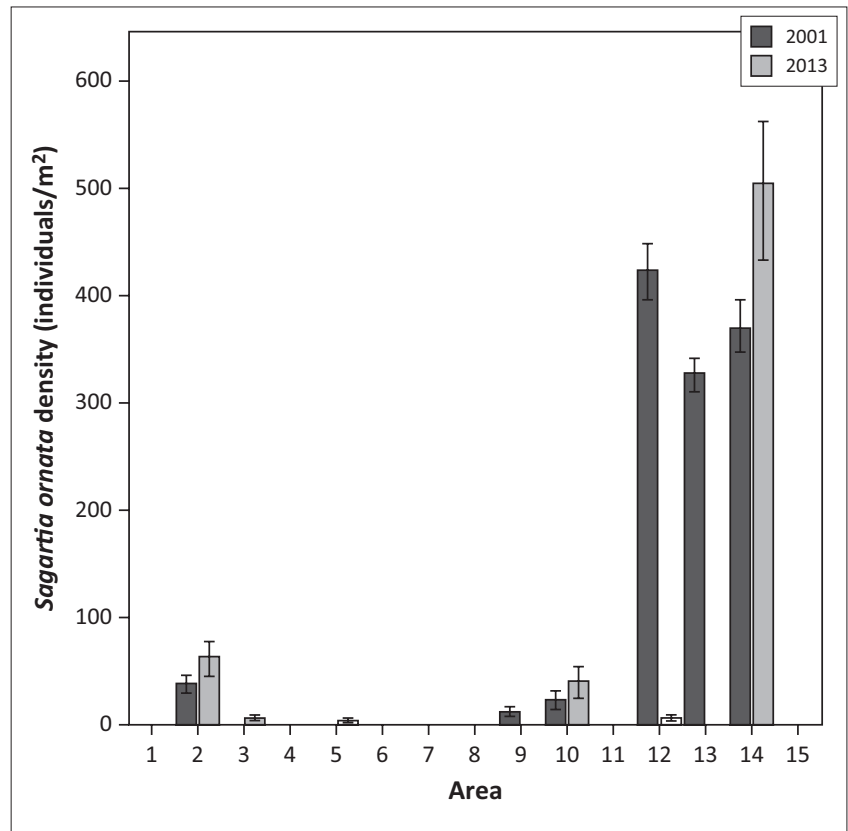

Source: Authors' own creation

FIGURE 2: Mean density (+SE) of Sagartia ornata recorded per $\mathrm{m}^{2}$ in 2001 and 2013. 
2013, respectively). Whilst S. ornata occurred in sandy areas covering underlying rock and in S. maritima beds in 2001, in 2013 it was no longer present in the S. maritima beds but was found instead in Nanozostera capensis beds (areas 2 and 5) and attached to rocks resting on fossilised oyster beds (areas 3 and 10). No anemones were found outside the WCNP within Saldanha Bay or on the open coast.

\section{Coelenteron contents analysis}

Only 35 of the 50 anemones whose coelentera were inspected contained prey items. Table 1 presents the percentages of numerical occurrence $(\% \mathrm{~N})$, mass $(\% \mathrm{M})$ and frequency of occurrence $(\% \mathrm{~F})$ as well as the IRI of prey items, which were identified to taxonomicgroup. This indexidentified polychaetes as the most important prey, occurring most frequently (i.e. in $83 \%$ of anemones), accounting for $53 \%$ of prey by numbers and $31 \%$ by mass. Amphipods were the second most important food item by mass (25\%) and IRI. Leptostraca and tanaids both occurred in the same numbers $(16 \%)$, although tanaids were recorded in more anemones $(29 \%)$ than the tiny leptostraca (20\%). Crabs, bivalves, gastropods and hemichordata were present in the diet of S. ornata.

\section{Community structure}

Invaded communities supported a significantly higher abundance (Mann-Whitney, $U_{(18)}=56.5, p<0.05$ ) (Figure 3a) and biomass (Mann-Whitney, $U_{(18)}=55, p<0.05$ ) (Figure 3b) of invertebrate individuals. Additionally, multivariate comparisons of community structure revealed significant differences in communities in terms of both abundance (ANOSIM, $R=0.799, p<0.01$ ) and biomass (ANOSIM, $R=0.916, p<0.01$ ) (Figure 4). These differences remained the same even when the contribution made by $S$. ornata was excluded. The SIMPER revealed that differences in community structure were not caused by the loss or gain of any one species, but rather by changes in the abundance and biomass of numerous indigenous species. These included increases in the tanaid Anatanais gracilis, the polychaete Orbinia angrapequensis, the hermit crab Diogenes brevirostris and gastropod Clionella sinuata and concurrent decreases in the gastropod Volvarina capensis and the crab Hymenosoma orbiculare in invaded areas. Invaded areas supported significantly higher species diversity $\left(H^{\prime}\right)$ (Mann-Whitney, $\left.U_{(18)}=78, p<0.05\right)$ (Figure 5).

TABLE 1: The prey items found in the coelentera of Sagartia ornata as well as their numerical percentage of occurrence $(\% \mathrm{~N})$, percentage by mass $(\% \mathrm{M})$ and their frequency of occurrence $(\% \mathrm{~F})$ in the diet.

\begin{tabular}{lcccc}
\hline Prey category & $\mathbf{\% N}$ & $\mathbf{\% M}$ & $\mathbf{\% F}$ & IRI \\
\hline Polychaetes & 53 & 31 & 83 & 6934 \\
Leptostraca & 16 & $\dagger$ & 20 & 323 \\
Tanaids & 16 & 3 & 29 & 532 \\
Amphipods & 10 & 25 & 29 & 1009 \\
Crabs & 1 & 3 & 3 & 11 \\
Bivalves & 1 & 14 & 3 & 43 \\
Gastropods & 2 & $\dagger$ & 3 & 6 \\
Hemichordata & 1 & 24 & 3 & 72 \\
\hline
\end{tabular}

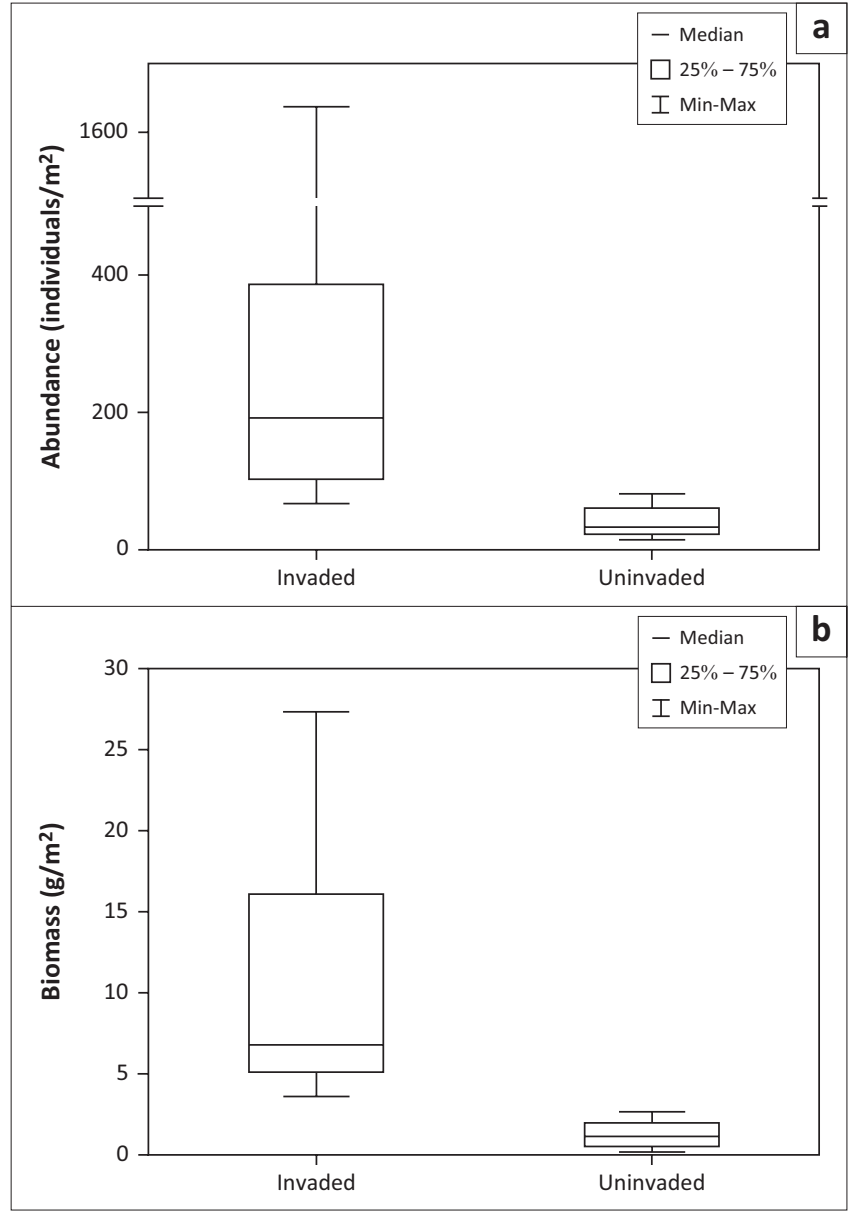

Source: Authors' own creation

FIGURE 3: Sagartia ornata (a) abundance (individuals per $\mathrm{m}^{2}$ ) (note scale break) and $(\mathrm{b})$ biomass $\left(\mathrm{g}\right.$ per $\mathrm{m}^{2}$ ) in invaded and uninvaded sites.

\section{Discussion}

Sagartia ornata has a wide native distribution that spans the Mediterranean, Britain and Western Europe (Acuña et al. 2004). This species was first recorded in South Africa in 2001, at which time it occurred only along Langebaan Lagoon's western shoreline within the WCNP (Robinson et al. 2004). Following this initial work, no follow-up studies have been conducted until now. This study found that $S$. ornata was still restricted to Langebaan Lagoon, although its distribution within the lagoon had changed.

Despite S. ornata living on rocky shores and in kelp holdfasts in its native habitat (Gibson et al. 2001), it occurs in different habitats in South Africa. In Langebaan Lagoon, S. ornata has been recorded in shallow sand partially covering underlying rocks, in S. maritima beds (Robinson et al. 2004), attached to loose rocks on fossilised oyster beds and in beds of the Cape eelgrass $N$. capensis. This shift in habitat is not uncommon for invading species. For example, the invasive zebra mussel Dreissena polymorpha that occurs on hard substrates in rivers and lakes in its native range occurs on soft sediments in its invaded range (Berkman et al. 2000). This exploitation of new habitats might reflect the adaptive ability often expressed by alien species (Berkman et al. 2000). The spread of S. ornata to 


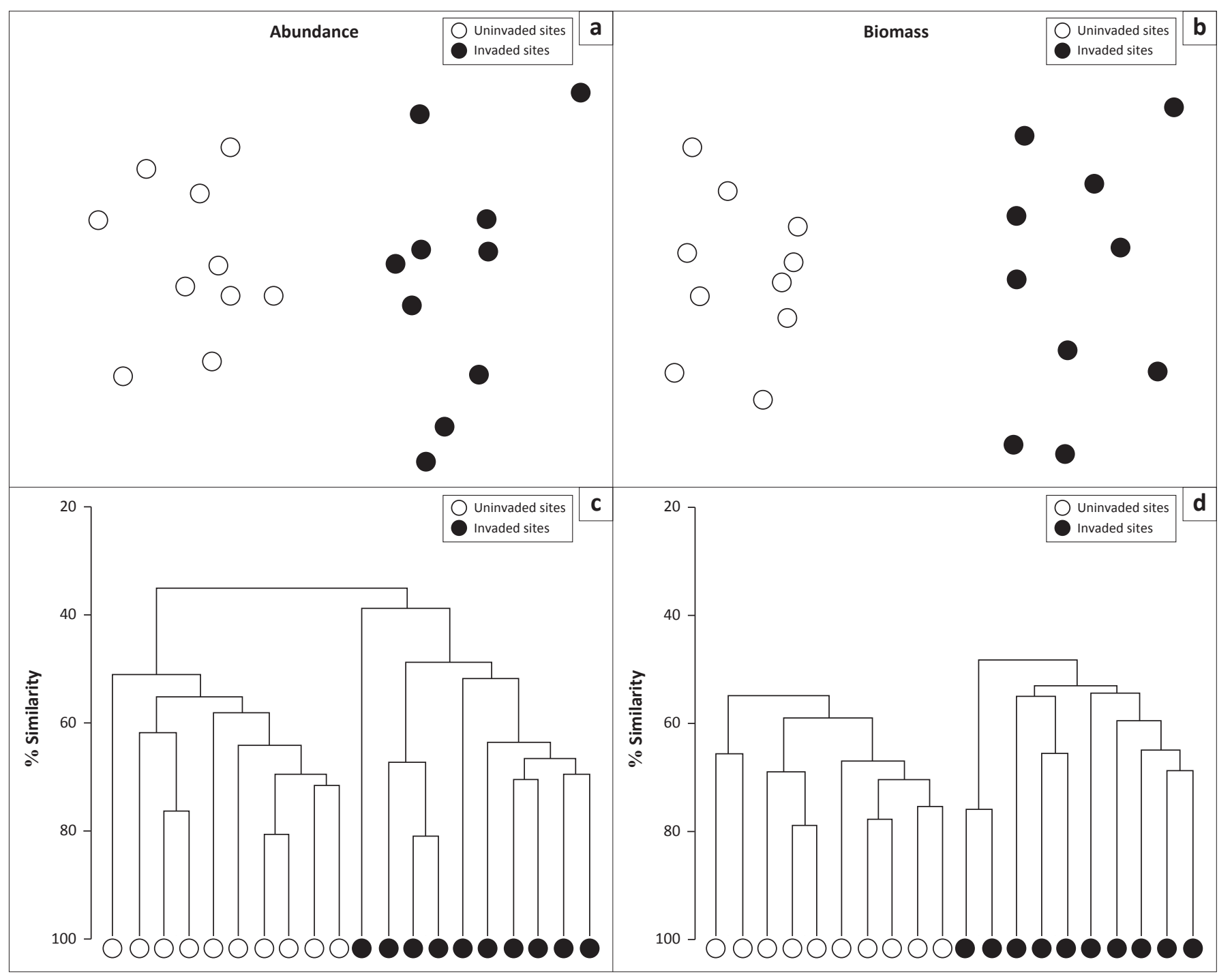

Source: Authors' own creation

FIGURE 4: Non-metric multidimensional scaling plot of species (a) abundances and (b) biomass of areas invaded and uninvaded by Sagartia ornata. Dendogram based on group-average clustering for species (c) abundances and (d) biomass for these areas. All data was fourth-root transformed. The contribution made by Sagartia ornata is included.

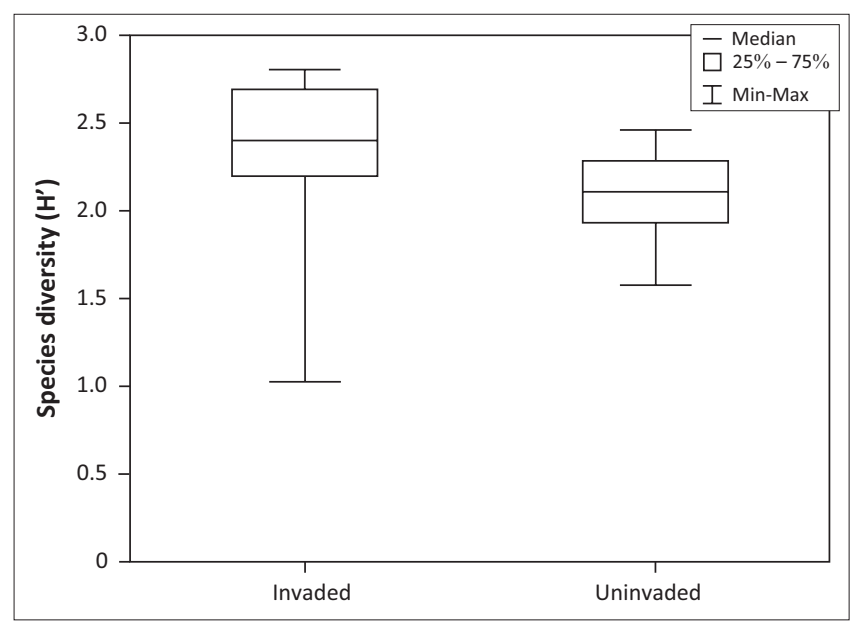

Source: Authors' own creation

FIGURE 5: Shannon-Wiener species diversity $\left(H^{\prime}\right)$ for invaded and uninvaded sites.

new areas within the park since 2001 is notable and is linked to its exploitation of new habitats (i.e. in N. capensis beds and the rather cryptic habitat of loose rocks resting on fossilised oyster beds). It is also possible that $S$. ornata might have been overlooked in the latter habitat in the 2001 survey, as it is not the type of habitat that was anticipated to support this anemone. It is unlikely, however, that this anemone will spread extensively within the lagoon because of the relatively restricted extent of the habitats in which it has been recorded. In addition to changes in distribution, the abundance of $S$. ornata has also changed, as more anemones were recorded during 2013 than during the 2001 survey. However, the reason for this change is not obvious. Whilst the 2001 and 2013 surveys were conducted at the same time of the year (i.e. seasonal variation is unlikely to be of importance), routine monitoring of this anemone may reveal the drivers of the observed changes in abundance.

Previous studies have shown that anemones can be important predators in marine communities (Kruger \& Griffiths 1997; Posey \& Hines 1991) and as such the impact of $S$. ornata as a predator on the sandy-shore communities within Langebaan Lagoon is of interest. The coelenteron 
content analysis revealed that $S$. ornata ate a very limited diet, sand-dwelling polychaetes and amphipods being the most important prey items. The diet of an anemone normally reflects the faunal communities supported in its habitat (Chintiroglou \& Koukouras 1992; Kruger \& Griffiths 1998) and as the sandy-shore communities provide habitat for sand-dwelling and burrowing species (Branch et al. 2010), it may explain their importance in the diet of S. ornata. Sea anemones are sessile passive feeders mostly relying on prey to come to them (Sebens 1981) and have various feeding mechanisms to meet their daily nutritional requirements. These include absorption of dissolved organic matter, forming of mutualisms with photosynthetic zooxanthellae (Tsuchida \& Potts 1994), filter-feeding (Lampitt \& Paterson 1987) and feeding macrophagously on either motile or wave-tumbled prey (Sebens 1981). Although the feeding mechanisms of $S$. ornata have not been investigated, it occurs in a sheltered habitat with little wave action, a habitat type where anemones rely to a great extent on mobile prey (Kruger \& Griffiths 1998). It is therefore likely that S. ornata employs a prey catching strategy, as is common to anemones in temperate regions (Kruger \& Griffiths 1996). The feeding mechanism of an anemone is an important determinant of its impact on the surrounding communities. Anemones relying on wave action to supply them with prey would not have direct impacts on communities, as prey items would already have been removed from source populations (Kruger \& Griffiths 1998). In contrast, anemones such as S. ornata that rely on mobile prey are more likely to affect their communities as prey are actively removed from communities.

Diet analyses can be affected by a variety of factors, such as poor preservation of specimens, egestion (Lampitt \& Paterson 1987), digestion rate and turnover times (Kruger \& Griffiths 1997), as they influence the retention time and quantities of prey items available for analysis (Kruger \& Griffiths 1998). In addition, diet can vary on a seasonal and temporal basis (Kruger \& Griffiths 1996). Thus, the present study cannot be considered an exhaustive analysis of S. ornata's diet. However, it does provide an indication of the taxa consumed and insight into the predatory role of S. ornata.

Although the ecological role of $S$. ornata has not been documented in its native range, it was anticipated that this anemone would negatively affect native communities as this is a well-documented impact associated with many sandyshore invaders (Grosholz et al. 2000; Robinson et al. 2007; Ross et al. 2004). As predicted this pattern was observed for S. ornata, with invaded areas supporting a higher invertebrate abundance, biomass and diversity, as well as altered communities. As these changes were not driven by the loss of the species that were found to dominate S. ornata's diet, it is unlikely that this anemone is exerting its impact on native communities through its role as a predator. Rather, these changes may be the result of impacts on the invaded habitat by S. ornata and indirect effects on native biota. This anemone appears to alter the surrounding habitat, consolidating sand and trapping coarse sediment (Robinson pers. obs.). This has been observed elsewhere where alien species have changed soft sediment systems by altering abiotic factors such as water movement and sediment characteristics (Berkman et al. 2000; McKinnon et al. 2009; Ruiz et al. 1997). In turn, sediment type and structure influence the distribution, abundance and biomass of associated species (Nel \& Branch 2013; Thrush et al. 2003). This may explain the higher invertebrate abundance, biomass and elevated diversity observed in the sites where S. ornata has invaded. Notably, the high abundance of tanaids recorded in the presence of $S$. ornata is likely a reflection of domination by coarser sediments, as these crustaceans are known to have reduced rates to tube building in the presence of sediments below $63 \mu \mathrm{m}$ (Krasnow \& Taghon 1997). In addition, tanaids themselves are known to change community structure by altering the habitat and preying on small and juvenile soft-bodied invertebrates (Oliver \& Slattery 1985). It is thus suggested that a synergy between the primary impacts of $S$. ornata on habitat structure and the secondary impacts of these small crustaceans ultimately result in the observed differences between invaded and uninvaded areas.

\section{Conclusion}

This study aimed to provide an updated baseline on the status and distribution of S. ornata, to assess the diet of this alien anemone and to investigate its impact on the structure of the sandy-shore communities of the WCNP. A survey of the lagoon found that $S$. ornata remained restricted to the WCNP, although its distribution had changed. Notably this anemone was recorded in N. capensis seagrass beds for the first time. Nonetheless it is unlikely that S. ornata will spread extensively within this marine protected area because of the restricted nature of the habitats in which it occurs. Diet analysis revealed the dominant prey items consumed by $S$. ornata were indigenous sand-dwelling polychaetes and amphipods. Multivariate analysis showed that in invaded areas this alien altered sandy-shore community structure, increased diversity, density and biomass of native invertebrates. Despite these impacts, the geographically restricted nature of the habitat types currently invaded by S. ornata limits the potential of this alien to negatively affect indigenous biota within the WCNP. However, routine monitoring of surrounding areas should be undertaken as the occurrence of $S$. ornata on rocky shores and in kelp beds in its native range suggests that this anemone could spread to outside the park.

\section{Acknowledgements}

The financial assistance of the National Research Foundation (NRF) and the NRF-DST Centre of Excellence for Invasion Biology are gratefully acknowledged. Opinions expressed and conclusions arrived at are those of the authors and are not necessarily to be attributed to the NRF. We are also grateful to the West Coast National Park for supporting the study and granting us research 
permits. Lastly, we would like to thank Ben Brooker, Michelle Jooste, Haley Pope and Saachi Sadchatheeswaran for assisting with fieldwork, Sheree Muller for laboratory assistance and Koebraa Peters and Dr Carol Simon for assisting with species identification.

\section{Competing interests}

The authors declare that they have no financial or personal relationships that may have inappropriately influenced them in writing this article.

\section{Authors' contributions}

T.B.R. (Stellenbosch University) was project leader and responsible for the project design. She helped with data collection, guided statistical analyses and contributed to writing the manuscript. C.S. (Stellenbosch University) undertook data collection and analysis and contributed to writing the manuscript.

\section{References}

Acuña, F.H., Excoffon, A.C. \& Griffiths, C.L., 2004, 'First record and redescription of the introduced sea anemone Sagartia ornata (Holdsworth, 1855) (Cnidaria: Actiniaria: Sagartiidae) from South Africa', African Journal of Zoology 39 314-318.

Berg, J., 1979, 'Discussion of methods of investigating the food of fishes, with reference to a preliminary study of the prey of Gobiusculus flavescens (Gobiidae)', Marine Biology 50, 263-273. http://dx.doi.org/10.1007/BF00394208

Berkman, P.A., Garton, D.W., Haltuch, M.A., Kennedy, G.W. \& Febo, L.R., 2000, 'Habitat shift in invading species: Zebra and quagga mussel population characteristics on shallow soft substrates', Biological Invasions 2, 1-6. http://dx.doi. org/10.1023/A:1010088925713

Bolton, J.J., Andreakis, N. \& Anderson, R.J., 2011, 'Molecular evidence for three separate cryptic introductions of the red seaweed Asparagopsis (Bonnemaisoniales, Rhodophyta) in South Africa', African Journal of Marine Science 33, 263-271. http://dx.doi.org/10.2989/1814232X.2011.600339

Branch, G.M., Griffiths, C.L., Branch, M.L. \& Beckley, L.E., 2010, Two oceans: A guide to marine life of southern Africa, Struik Nature, Cape Town.

Briski, E., Bailey, S.A. \& Maclsaac, H.J., 2011, 'Invertebrates and their dormant eggs transported in ballast sediments of ships arriving to the Canadian coasts and the
Laurentian Great Lakes', Limnology and Oceanography 56, 1929-1939. http:// dx.doi.org/10.4319/lo.2011.56.5.1929

Carlton, J.T., 1996, 'Pattern, process, and prediction in marine invasion ecology' Biological Conservation 78, 97-106. http://dx.doi.org/10.1016/0006-3207(96 00020-1

Chintiroglou, C. \& Koukouras, A., 1992, 'The feeding habits of three Mediterranean sea anemone species, Anemonia viridis (Forskål), Actinia equina (Linnaeus) and Cereus pedunculatus (Pennant)', Helgoländer meeresuntersuchungen 46, 53-68.

Cinar, M.E., 2013, 'Alien polychaete species worldwide: Current status and their impacts', Journal of the Marine Biological Association of the United Kingdom 93, 1257-1278. http://dx.doi.org/10.1017/S0025315412001646

Clark, B.M. \& Griffiths, C.L., 2012, 'Western pea crabs Pinnixa occidentalis (Rathbun, 1894) (Brachyura: Thoracotremata: Pinnotheroidea) invade Saldanha Bay, South Africa', African Journal of Marine Science 34, 153-156. http://dx.doi.org/10.298 Africa', African Journal of $M$.
9/1814232X.2012.675128

Clarke, K.R. \& Warwick, R.M., 2001, Change in marine communities: An approach to statistical analysis and interpretation, 2nd edn., PRIMER-E, Plymouth.

Gibson, R., Hextall, B. \& Rogers, A., 2001, Photographic guide to the sea and shore life of Britain and north-west Europe, Oxford University Press, New York.

Grosholz, E.D., Ruiz, G.M., Dean, C.A., Shirley, K.A., Maron, J.L. \& Connors, P.G., 2000, 'The impacts of a nonindigenous marine predator in a California Bay', Ecology 81 1206-1224. http://dx.doi.org/10.1890/0012-9658(2000)081[1206:TIOANM]2.0. $\mathrm{CO} ; 2$

Gurevitch, J. \& Padilla, D.K., 2004, 'Are invasive species a major cause of extinctions?', Trends in Ecology and Evolution 19, 470-474. http://dx.doi.org/10.1016/j. tree.2004.07.005

Hewitt, C.L., Gollasch, S. \& Minchin, D., 2009, 'The vessel as a vector - Biofouling, ballast water and sediments', Biological Invasions in Marine Ecosystems Ecological Studies 204, 117-131. http://dx.doi.org/10.1007/978-3-540-79236-9_6

Klein, G., Maclntosh, K., Kaczmarska, I. \& Ehrman, J.M., 2010, 'Diatom survivorship in ballast water during trans-Pacific crossings', Biological Invasions 12, 1031-1044. http://dx.doi.org/10.1007/s10530-009-9520-6
Krasnow, L.D. \& Taghon, G.L., 1997, 'Rate of tube building and sediment particle size selection during tube construction by the tanaid crustacean, Leptochelia dubia', section during tube construction by the tanaid crustacean,
Estuaries 20, 534-546. http://dx.doi.org/10.2307/1352612

Kruger, L.M. \& Griffiths, C.L., 1996, 'Sources of nutrition in intertidal sea anemones from the south-western Cape, South Africa', South African Journal of Zoology 31, $110-119$.

Kruger, L.M. \& Griffiths, C.L., 1997, 'Digestion rates of prey eaten by intertidal sea anemones from the south-western Cape, South Africa', South African Journal of Zoology 32, 101-105.

Kruger, L.M. \& Griffiths, C.L., 1998, 'Sea anemones as secondary consumers on rocky shores in the south-western Cape, South Africa', Journal of Natural History 32, 629-644. http://dx.doi.org/10.1080/00222939800770331

Kruger, N., Branch, G.M., Griffiths, C.L. \& Field, J.G., 2005, 'Changes in the epibenthos of Saldanha Bay, South Africa, between the 1960s and 2001: An analysis based on dredge samples', African Journal of Marine Science 27, 471-477. http://dx.doi. org/10.2989/18142320509504105

Lampitt, R.S. \& Paterson, G.L.J., 1987, 'The feeding-behavior of an abyssal seaanemone from in situ time lapse photographs and trawl samples', Oceanologica Acta 10, 455-461.

McKinnon, J.G., Gribben, P.E., Davis, A.R., Jolley, D.F. \& Wright, J.T., 2009, 'Differences in soft-sediment macrobenthic assemblages invaded by Caulerpa taxifolia compared to uninvaded habitats', Marine Ecology - Progress Series 380, 59-71. http://dx.doi.org/10.3354/meps07926

Mead, A., Carlton, J.T., Griffiths, C.L. \& Rius, M., 2011a, 'Revealing the scale of marine bioinvasions in developing regions: A South African re-assessment', Biological Invasions 13, 1991-2008. http://dx.doi.org/10.1007/s10530-011-0016-9

Mead, A., Carlton, J.T., Griffiths, C.L. \& Rius, M., 2011b, 'Introduced and cryptogenic marine and estuarine species of South Africa', Journal of Natural History 45, 24632524. http://dx.doi.org/10.1080/00222933.2011.595836

Mead, A., Griffiths, C.L., Branch, G.M., McQuaid, C.D., Blamey, L.K., Bolton, J.J. et al., 2013, 'Human-mediated drivers of change: Impacts on coastal ecosystems and marine biota of South Africa', African Journal of Marine Science 35, 403-425. http://dx.doi.org/10.2989/1814232X.2013.830147

Molnar, J.L., Gamboa, R.L., Revenga, C. \& Spalding, D., 2008, 'Assessing the global threat of invasive species to marine biodiversity', Frontiers in Ecology and the Environment 6, 485-492. http://dx.doi.org/10.1890/070064

Nel, P. \& Branch, G.M., 2013, 'Assessment of the abundance and distribution of burrowing sandprawns and mudprawns (Callichirus and Upogebia species) in Langebaan Lagoon, South Africa', African Journal of Marine Science 35, 1-14. http://dx.doi.org/10.2989/1814232X.2013.795914

Oliver, J.S. \& Slattery, P.N., 1985, 'Effects of crustacean predators on species composition and population structure of soft-bodied infauna from McMurdo sound, Antarctica', Ophelia 24, 155-175. http://dx.doi.org/10.1080/00785326. 1985.10429725

Olivier, D., Heinecken, L. \& Jackson, S., 2013, 'Mussel and oyster culture in Saldanha Bay, South Africa: Potential for sustainable growth, development and employment creation', Food Security 5, 251-267. http://dx.doi.org/10.1007/s12571-013$0244-1$

Peters, K., Griffiths, C. \& Robinson, T.B., 2014, 'Patterns and drivers of marine bioinvasions in eight Western Cape harbours, South Africa', African Journal of Marine Science 36, 49-57. http://dx.doi.org/10.2989/1814232X.2014. 890669

Pimentel, D., Zuniga, R. \& Morrison, D., 2005, 'Update on the environmental and economic costs associated with alien-invasive species in the United States', Ecological Economics 52, 273-288. http://dx.doi.org/10.1016/j. ecolecon.2004.10.002

Pitcher, G.C. \& Calder, D., 1998, 'Shellfish mariculture in the Benguela system: Phytoplankton and the availability of food for commercial mussel farms in Saldanha Bay, South Africa', Journal of Shellfish Research 17, 15-24.

Posey, M.H. \& Hines, A.H., 1991, 'Complex predator-prey interactions within an estuarine benthic community', Ecology 72, 2155-2169. http://dx.doi. org/10.2307/1941567

Robinson, T.B., Branch, G.M., Griffiths, C.L. \& Govender, A., 2007, 'The invasion and subsequent die-off of Mytilus galloprovincialis in Langebaan Lagoon, South Africa: Effects on natural communities', Marine Biology 152, 225-232. http://dx.doi. org/10.1007/s00227-007-0697-x

Robinson, T.B. \& Griffiths, C.L., 2002, 'Invasion of Langebaan Lagoon, South Africa, by Mytilus galloprovincialis - effects on natural communities', African Zoology 37, 151-158.

Robinson, T.B., Griffiths, C.L. \& Kruger, N., 2004, 'Distribution and status of marine invasive species in and bordering the West Coast National Park', Koedoe 47, 7987. http://dx.doi.org/10.4102/koedoe.v47i1.73

Robinson, T.B., Griffiths, C.L., McQuaid, C.D. \& Rius, M., 2005, 'Marine alien species of South Africa - status and impacts', African Journal of Marine Science 27, 297-306. http://dx.doi.org/10.2989/18142320509504088

Ross, D.J., Johnson, C.R., Hewitt, C.L. \& Ruiz, G.M., 2004, 'Interaction and impacts of two introduced species on a soft-sediment marine assemblage in SE Tasmania', Marine Biology 144, 747-756. http://dx.doi.org/10.1007/s00227003-1223-4

Ruiz, G.M., Carlton, J.T., Grosholz, E.D. \& Hines, A.N., 1997, ‘Global invasion of marine and estuarine habitats by non-indigenous species: Mechanisms, extent, and consequences', American Zoology 37, 621-632.

Sebens, K.P., 1981, 'The allometry of feeding, energetics and body size in three sea anemone species', Biological Bulletin 161, 152-171. http://dx.doi. org/10.2307/1541115 
Seebens, H., Gastner, M.T. \& Blasius, B., 2013, 'The risk of marine bioinvasion caused by global shipping', Ecology Letters 16, 782-790. http://dx.doi.org/10.1111/ ele.12111

Strain, E.M.A \& Johnson, C.R., 2013, 'The effects of an invasive habitat modifier on the biotic interactions between two native herbivorous species and benthic habitat in a subtidal rocky reef ecosystem', Biological Invasions 15, 1391-1405. http:// dx.doi.org/10.1007/s10530-012-0378-7

Thrush, S.F., Hewitt, J.E., Norkko, A., Nicholls, P.E., Funnell, G.A. \& Ellis, J.I., 2003 'Habitat change in estuaries: Predicting broad-scale responses of intertidal macrofauna to sediment mud content', Marine Ecology Progress Series 263, 101112. http://dx.doi.org/10.3354/meps263101

Tsuchida, C.B. \& Potts, D.C., 1994, 'The effects of illumination, food and symbionts on growth of the sea anemone Anthopleura elegantissima (Brandt, 1835) I. Ramet growth', Journal of Experimental Marine Biology and Ecology 183, 227-242. http://dx.doi.org/10.1016/0022-0981(94)90089-2

Wonham, M.J., Carlton, J.T., Ruiz, G.M. \& Smith, L.D., 2000, 'Fish and ships: Relating dispersal frequency to success in biological invasions', Marine Biology 136, 1111-1121. http://dx.doi.org/10.1007/s002270000303 